\title{
Stress protein accumulation as an indicator of impact by the petroleum industry in Todos os Santos Bay, Brazil
}

\author{
I.A. Nascimento*a , M.B.N. Leite ${ }^{a}$, G. Sansone ${ }^{b}$, S.A. Pereira ${ }^{a}$, D.H. Smith ${ }^{a}$ \\ Institute of Biology, Federal University of Bahia, Salvador, Bahia, Brazil

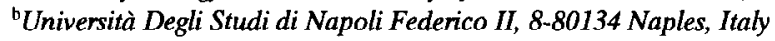

\begin{abstract}
The relative concentrations of stress proteins in juvenile mangrove oysters (Crassostrea rhizophorae), from six study sites in Todos os Santos Bay, Bahia, Brazil, were used to evaluate the possibility of chronic environmental impact induced by 40 years of exposure to the local petroleum industry. Replicated tissue samples from oysters at four sites associated with the extraction, transport and refinement of petroleum, and from two control sites, were used for stress protein $(60 \mathrm{kDa})$ determination. The relative levels of stress proteins were statistically compared by standard methods. Friedman nonparametric analysis of variance, followed by multiple comparisons among samples, revealed significant differences in stress protein levels. Oysters from sites associated with the extraction and transport of petroleum had the highest relative concentrations of stress proteins, while the control areas revealed minimum concentrations. Samples from the refinery site, where oyster populations were severely reduced, did not differ from the control sites. Comparisons with parallel studies on the toxicity of aquatic substrates at the same sites revealed that stress protein analyses were useful in evaluating chronic environmental impact, within the tolerance limits of $C$. rhizophorae, but that the stress response diminished significantly when conditions approached the lethal limits for this species. The stress protein response appears to serve as a valid biomonitoring method under chronic, sublethal exposures, before biological responses become evident at the organismic or population levels, but may not serve well when the stressor intensity is at or near the lethal tolerance level. (C) 1998 Elsevier Science Ltd and AEHMS. All rights reserved.
\end{abstract}

Keywords: Petroleum; Chronic impact; Stress proteins; Crassostrea rhizophorae

\section{Introduction}

Exposure of cells to stressing agents results in a rapidly expressed set of metabolic changes, curr-

*Corresponding author. ently referred to as the 'stress response' (Rosen et al., 1986). These changes include the activation and elevated expression of a small set of genes, resulting in the increased synthesis and accumulation of 'stress proteins' (SPs), and a concomitant reduction in the translation of most species of preexisting m-RNAs, and thus a reduction of the normal pro- 
tein synthesis (Schlesinger, 1986; Sanders, 1990). Since it was first observed, in Drosophila exposed to temperature stress (Ashburner and Bonner, 1979), the stress response has been reported in a variety of other organisms, under different stressors, leading to the hypothesis that it is a highly conserved and ubiquitous response to adverse environmental changes (Desahaies et al., 1988; Convington, 1992). In view of this, the stress response has recently (Sanders, 1990) been suggested as an approach to evaluate environmentally induced damages. This approach uses the detection of stress protein induction in organisms to make inferences about environmental conditions in their surroundings.

Toxic effects are best known and understood at the cellular level. However, the specific relationships between biochemical responses and adverse effects on populations and ecosystems have often been unclear making it difficult to interpret the higher level biological consequences of a biochemical change (Neff, 1984). Thus, biochemical responses should be correlated with other parameters which reflect adverse effects at the organismal and population levels, to be validated as molecular indicators of adverse biological effects (Lindquist, 1986). Sanders et al. (1992) suggested that one way to minimize the difficulty of interpreting the higher level biological consequences of a biochemical change is to select as indicators the primary biochemical events which are involved in protecting and defending the cells from environmental insults. One well conserved defense response involves the induction of stress proteins. The stress protein $60 \mathrm{kDa}$ is highly inducible in response to environmental stressors, even though this response may cease in situations where the effects of the stressor, at or near the lethal tolerance limit of the species, has become evident at the organism level (Nascimento et al., 1994).

In the northeastern area of Todos os Santos Bay, Bahia, Brazil, the extraction, transport and refinement of petroleum is the most conspicuous industrial activity. It was implanted 40 years ago and, except for a few brief, localized studies to determine acute impact from oil spills, no survey has been carried out in this area to evaluate the possible chronic pollution effects generated during this period. The region is bordered by extensive mangrove commu- nities, whose characteristics and necessary preservation make it imperative to prevent and/or to determine the extension of any impact.

The purpose of the present study was to evaluate the applicability of using stress protein $60 \mathrm{kDa}$ as an indicator of impact, generated primarily by the petroleum industry. This study was executed to complement the monitoring studies already being carried out by multidisciplinary field teams from the Institute of Biology, Federal University of Bahia (Peso de Aguiar and Almeida, 1996).

\section{Material and methods}

Sampling stations in northeastern Todos os Santos Bay $\left(\sim 12^{\circ} 42^{\prime} \mathrm{S}, 38^{\circ} 37^{\prime} \mathrm{W}\right)$ were selected based on the seawater current patterns and locations of the major industrial activities (Fig. 1), such as the refinery (Station 1), transport terminal (Station 2), transport lane (Station 3) and extraction (Station 4) of petroleum. Because assessing the toxicity of contaminants in situ relies on comparing the possibly polluted systems with unperturbed systems, two controls (Stations 5 and 6) were selected outside the area of petroleum activity, at the extreme south of Todos os Santos Bay $\left(\sim 13^{\circ} 03^{\prime} \mathrm{S}\right.$, $38^{\circ} 47^{\prime} \mathrm{W}$ ).

Juvenile mangrove oysters, Crassostrea rhizophorae, 1.2 to $1.8 \mathrm{~cm}$ in length, were collected from the mangrove roots at each station, immediately dipped in liquid nitrogen and transported to the laboratory for stress protein analysis. Sample preparation was performed using the methods of Dyer (1991). Oysters were opened by cutting the adductor muscle, and the tissues were removed and homogenized in $150 \mu \mathrm{l}$ of buffer $(150 \mathrm{mM}$ TRIS-HCL, $\mathrm{pH} 7.8,1 \mu \mathrm{M}$ phenylmethylsulfonyl fluoride). Homogenates were centrifuged at $14,000 \times \mathrm{g}$. (Microcentrifuge Eppendorf model 5402 ) at $4^{\circ} \mathrm{C}$ for $30 \mathrm{~min}$. The supernatants were then collected, and protein concentrations were determined (Bradford, 1976).

Proteins were separated on $12.5 \%$ polyacrylamide gels with a 5\% stacking gel as described by Blattler et al. (1972), using the buffer system described by Laemmli (1970). Prestained, low molecular weight standards were used to identify the stress proteins. After electrophoresis, the proteins 


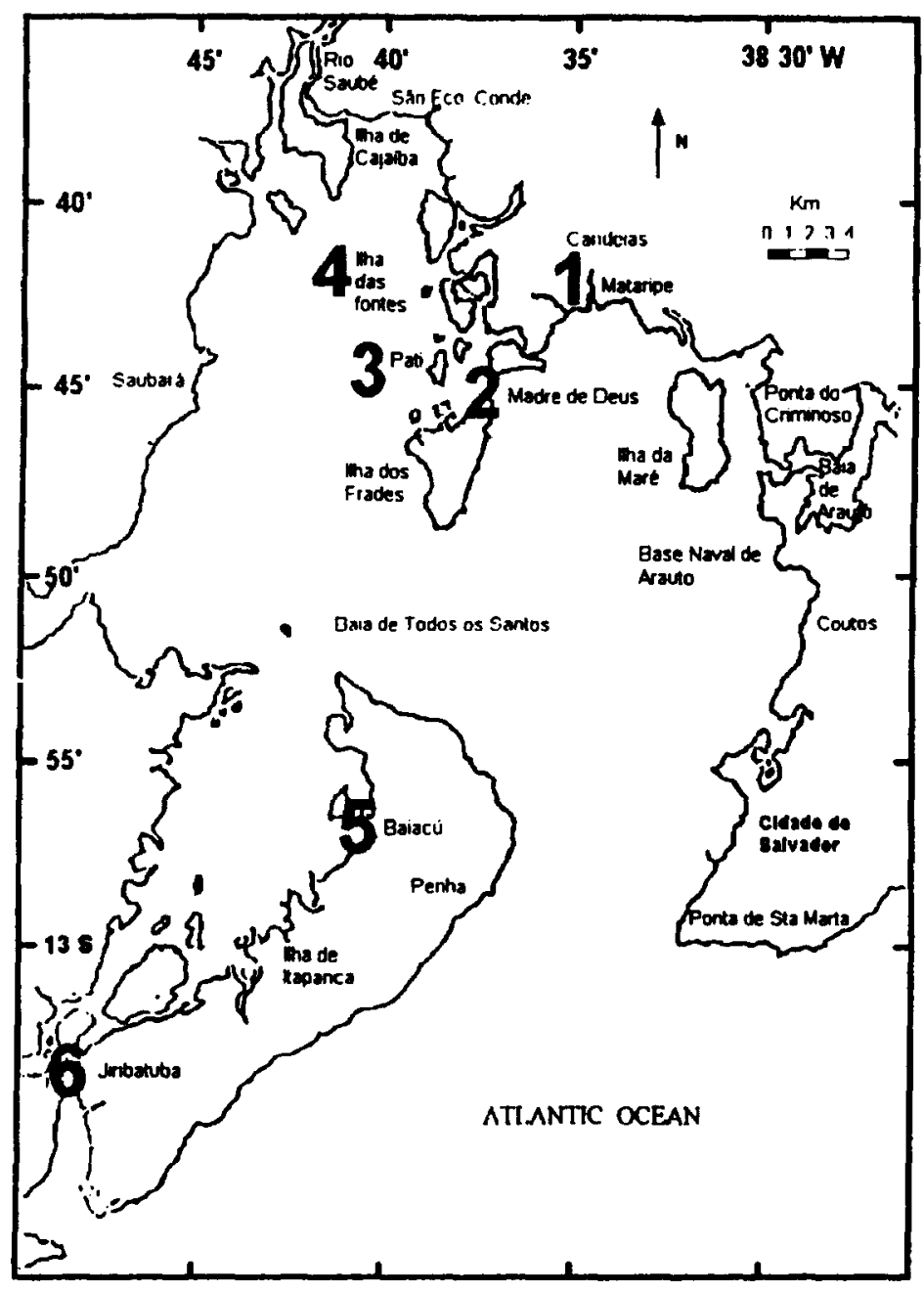

Fig. 1. Sampling stations at Todos os Santos Bay, Bahia, Brazil. $1=$ Refinery; $2=$ transport terminal; $3=$ transport lane; $4=$ extraction; $5=$ control; $6=$ control (reference).

were transferred to nitrocellulose by Western Blotting using a transfer buffer containing SDS (1\%), $0.192 \mathrm{M}$ glycine in $0.025 \mathrm{M}$-TRIS and methanol $(20 \% \mathrm{v} / \mathrm{v})$, at $\mathrm{pH} 8.3$. The gels were subjected to 25 $\mathrm{v}$ for $15 \mathrm{~h}$ at $4^{\circ} \mathrm{C}$. Transfers were blocked in $25 \mathrm{mM}$ TRIS-HCl buffer ( $\mathrm{pH} \mathrm{8.0)} \mathrm{containing} \mathrm{BSA} \mathrm{(3 \% ),}$ $137 \mathrm{mM} \mathrm{NaCl}$, and $2.7 \mathrm{mM} \mathrm{KCl}$ (TBS). Transfers were then washed with TBS containing Tween-20 (0.5\% TTBS).

The nitrocellulose membranes were probed using a polyclonal rabbit antibody raised against SP60 from the moth Heliothis sp. (StressGen Bio- technology Corp., Victoria, B.C., Canada). Blots were incubated for $90 \mathrm{~min}$ at room temperature with SP60 antibody and rinsed several times with TBS containing $0.5 \%$ Tween-20 (TTBS). The blots were incubated with goat anti-rabbit alkaline phosphatase conjugated antibody for $90 \mathrm{~min}$. They were then washed several times with TTBS and TBS. Colour development of the immunoreactive bands was initiated with 5-bromo 4-chloro 4-indolyl phosphatase $t$-toluidine salt and $p$-nitro blue tetrazolium chloride in $100 \mathrm{mM} \mathrm{NaHCO}$ buffer containing $1 \mathrm{mM} \mathrm{MgCL}_{2}$, $\mathrm{pH} 9.8$. 
To make a relative quantification of the immunoreactive bands, gels were loaded with a serial dilution of an initial volume of sample buffer containing $100 \mu \mathrm{g}$ of total protein with a range of 100 to $1.56 \mu \mathrm{g}$ distributed in seven concentrations. Stress protein concentrations of each sample, relative to control values, were expressed as the inverse of the total protein at detection limit of the sample, divided by the total protein at detection limit of the control according to the following equation (Sanders et al., 1991)

Relative [hsp60] $=\left(X_{\text {sample }} / X_{\text {control }}\right)^{-1}$

where $X$ is $\mu \mathrm{g}$ total protein.

After quantification, total values for each sample and control, over all the dilutions, were compared using Friedman nonparametric ANOVA and a subsequent multiple comparison procedure, both based on ranked responses (Conover, 1971). This approach led not only to an ordination of the stations in terms of stress protein responses, but also showed the significance of the differences among stations. Finally, a cluster analysis based on Gower's general similarity coefficient and cluster algorithm UPGMA (Unweighted Pair-Group Method using Arithmetic means; Sneath and Sokal, 1973) was made to illustrate similarities and distances among stations.

\section{Results and discussion}

Immunoblotting with the SP60 polyclonal antibody showed specific immunoreactivity in the oyster tissues, as indicated by standard markers, at the detection limits of the samples in the serial dilution adopted in this study (Table 1). By using the stress protein quantification method described by Sanders et al. (1991), the relative stress protein reactions were represented as discrete, whole number multiples of control station (Station 6) reaction. Parametric ANOVA was consequently inappropriate for comparisons among stations. The Friedman nonparametric ANOVA, and subsequent multiple comparisons procedure, both based on ranked responses, was appropriate and efficient in comparing the results among stations. Separate tests were treated as independent blocks for the purpose of analysis (Table 2).
Based on ranked results, the mean SP response was highest at Station 4 (extraction), which differed significantly from the control Stations 5 and 6 $(p=0.036$ and $p=0.001$, respectively) and from Station 1 (refinery; $p=0.012$ ), but not from Stations 2 (terminal) and 3 (transport). The reference control (Station 6) was significantly below all the other stations except for Station 1 and Station 5 (Table 3).

A cluster analysis based on Gower's general similarity coefficient and clustering algorithm UPGMA, revealed Stations 2 and 3 to be most similar in their responses $(\mathrm{Sg}=0.786)$, followed by Station 4 with $\mathrm{Sg}=0.593$ to Group 2, 3. A second cluster was formed by Stations 1 and $5(\mathrm{Sg}=0.710)$, followed by Station 6, the reference control $(\mathrm{Sg}=0.664)$. These two clusters subsequently joined with a between group similarity of $\mathrm{Sg}=0.459$ (Table 4).

Based on results of toxicity tests reported elsewhere (Nascimento, 1996) the refinery (Station 1) was the most impacted of the six study sites. The oyster banks there are depleted and the remaining individuals have low condition indices. The level of stress protein response at Station 1, however, is similar to the controls (Stations 5 and 6), indicating that the stress response had ceased at Station 1. The data support the hypothesis of increasing concentrations of stress protein (at Stations 2, 3 and 4) until the stress factors approach the response limit of the species (at Station 1), and agree with previous data from Nascimento et al. (1994) and Nascimento (1996) who showed that continuous exposure to severe environmental conditions may lead to a physiological state in which the animal can no longer maintain the stress response and recover.

One must bear in mind that the stress protein response is an adaptation which indicates the occurrence of primary biochemical events involved in protecting and defending the cells from environmental insults. Consequently, this response is several steps away from the secondary effects which lead to abnormalities or mortality. There should therefore be a temporal gap between the different biological response levels. Biotic responses to environmental perturbations begin at the molecular/ cellular level, extending upward to tissues and organs, whose responses occur before changes are 
Table 1

Detection limits of SP60 observed at serial dilutions of total proteins from 1.56 to $100 \mu \mathrm{g}$ for juvenile oyster (Crassostrea rhizophorae) tissue samples from four sampling stations exposed to activities of the petroleum industry and two controls $(n=4$ specimens per test).

\begin{tabular}{|c|c|c|c|c|c|c|c|}
\hline \multirow[t]{2}{*}{ Stations } & \multicolumn{7}{|c|}{ Conc $(\mu \mathrm{g})$} \\
\hline & 100 & 50 & 25 & 12.5 & 6.25 & 3.12 & 1.56 \\
\hline \multicolumn{8}{|l|}{$\mathbf{R 1}$} \\
\hline St. 6 (control) & $\mathbf{x}$ & $\mathrm{x}$ & $\mathrm{x}$ & $\mathrm{x}$ & & & \\
\hline St. 5 (control) & $\mathbf{x}$ & $\mathbf{x}$ & $\mathbf{x}$ & & & & \\
\hline St. 4 (marine extraction) & & $\mathbf{x}$ & $\mathrm{x}$ & $\mathbf{x}$ & $\mathrm{x}$ & $\mathrm{x}$ & \\
\hline St. 3 (marine transport lane) & $\mathrm{x}$ & $\mathrm{x}$ & $\mathbf{x}$ & $\mathbf{x}$ & & & \\
\hline St. 2 (marine terminal) & $\mathrm{x}$ & $\mathbf{x}$ & $\mathrm{x}$ & $\mathrm{x}$ & & & \\
\hline St. 1 (shoreline refinery) & $\mathrm{x}$ & $\mathrm{x}$ & $\mathrm{x}$ & $\mathrm{x}$ & & & \\
\hline \multicolumn{8}{|l|}{$\mathbf{R 2}$} \\
\hline St. 6 (control) & $\mathbf{x}$ & $\mathrm{x}$ & $\mathrm{x}$ & $x$ & & & \\
\hline St. 5 (control) & $\mathrm{x}$ & $\mathbf{x}$ & $\mathrm{x}$ & $\mathbf{x}$ & & & \\
\hline St. 4 (marine extraction) & $\mathrm{x}$ & $\mathbf{x}$ & $\mathrm{x}$ & $\mathrm{x}$ & $\mathrm{x}$ & $\mathrm{x}$ & $x$ \\
\hline St. 3 (marine transport lane) & $\mathbf{x}$ & $\mathrm{x}$ & $x$ & $\mathrm{x}$ & $\mathrm{x}$ & $\mathrm{x}$ & $\mathrm{x}$ \\
\hline St. 2 (marine terminal) & $\mathrm{x}$ & $\mathrm{x}$ & $x$ & $\mathbf{x}$ & $\mathrm{x}$ & $\mathrm{x}$ & \\
\hline St. 1 (shoreline refinery) & $\mathrm{x}$ & $\mathrm{x}$ & $\mathrm{x}$ & $\mathrm{x}$ & $\mathrm{x}$ & & \\
\hline \multicolumn{8}{|l|}{$\mathbf{R 3}$} \\
\hline St. 6 (control) & $\mathrm{x}$ & $\mathbf{x}$ & $\mathrm{x}$ & $\mathrm{x}$ & $\mathrm{x}$ & & \\
\hline St. 5 (control) & $\mathbf{x}$ & $\mathbf{x}$ & $\mathrm{x}$ & & & & \\
\hline St. 4 (marine extraction) & $x$ & $\mathbf{x}$ & $x$ & $\mathrm{x}$ & $\mathrm{x}$ & $\mathrm{x}$ & \\
\hline St. 3 (marine transport lane) & $\mathrm{x}$ & $\mathbf{x}$ & $x$ & $\mathrm{x}$ & $\mathbf{x}$ & $\mathrm{x}$ & \\
\hline St. 2 (shoreline terminal) & $\mathbf{x}$ & $\mathbf{x}$ & $\mathrm{x}$ & $\mathrm{x}$ & $\mathrm{x}$ & $\mathrm{x}$ & \\
\hline St. 1 (refinery) & $\mathrm{x}$ & $\mathrm{x}$ & $x$ & $\mathrm{x}$ & & & \\
\hline \multicolumn{8}{|l|}{$\mathbf{R} 4$} \\
\hline St. 6 (control) & $\mathrm{x}$ & $\mathrm{x}$ & $\mathrm{x}$ & $\mathrm{x}$ & $x$ & $\mathbf{x}$ & \\
\hline St. 5 (control) & $\mathbf{x}$ & $\mathbf{x}$ & $\mathbf{x}$ & $\mathrm{x}$ & & & \\
\hline St. 4 (marine extraction) & $\mathrm{x}$ & $\mathrm{x}$ & $x$ & $\mathbf{x}$ & $\mathrm{x}$ & $\mathbf{x}$ & \\
\hline St. 3 (marine transport lane) & $\mathrm{x}$ & $\mathbf{x}$ & $\mathrm{x}$ & $\mathrm{x}$ & $\mathbf{x}$ & & \\
\hline St. 2 (marine terminal) & $\mathbf{x}$ & $\mathbf{x}$ & $\mathrm{x}$ & $\mathbf{x}$ & $\mathbf{x}$ & $\mathrm{x}$ & \\
\hline St. 1 (shoreline refinery) & $\mathbf{x}$ & $\mathrm{x}$ & $\mathbf{x}$ & $\mathrm{x}$ & $\mathbf{x}$ & & \\
\hline
\end{tabular}

observed in populations and ecosystems (Sanders, 1990). Thus, the major advantage of this indicator approach is that the events at a cellular level tend to be more sensitive than stress indices at the organismal level and may provide an early warning of higher order biological effects.
It is known that the demand for SPs increases under adverse conditions, when they perform functions of renaturing damaged peptides and resolubilizing protein aggregates that could be formed as a consequence of environmentally induced damages (Rothman, 1989). Even though 
Table 2

Relative values of minimum stress protein level (MSPL), determined as the inverse of total protein at the detection limit of samples, divided by the total protein at detection limit of the control

\begin{tabular}{lllllll}
\hline & \multicolumn{5}{c}{ Stations } \\
\cline { 2 - 7 } & 1 & 2 & 3 & 4 & 5 & 6 \\
\hline MSPL & 4.0 & 2.0 & 2.0 & 4.0 & 2.0 & 1.0 \\
& 0.5 & 4.0 & 4.0 & 8.0 & 1.0 & 1.0 \\
& 4.0 & 8.0 & 8.0 & 8.0 & 4.0 & 1.0 \\
& 1.0 & 8.0 & 2.0 & 4.0 & 4.0 & 1.0 \\
$\bar{X}$ & & & & & & \\
$S_{x}$ & 2.37 & 5.50 & 4.00 & 6.00 & 2.75 & 1.00 \\
& 1.63 & 2.59 & 2.44 & 2.00 & 1.29 & 0.00 \\
\hline
\end{tabular}

Table 3

Results of multiple comparisons, based on Friedman's Test, of the ranked stress protein values among sampling stations: Station 1: shoreline refinery; Station 2: marine transport terminal; Station 3: marine transport lane; Station 4: marine extraction site; Station 5: control 1; Station 6: control 2 (reference). The stations are ordered by their mean ranks from four replicate tests.

\begin{tabular}{llllllll}
\hline & \multicolumn{9}{l}{ Stations $>$} & & & \\
\cline { 3 - 7 } Stn. & Mean rank & 6 & 1 & 5 & 3 & 2 & 4 \\
\hline 6 & 1.50 & - & & & & \\
1 & 2.63 & NS & - & & & \\
5 & 3.13 & NS & NS & - & & \\
3 & 3.88 & $*$ & NS & NS & - & & \\
2 & 4.63 & $* *$ & $*$ & NS & NS & - & NS \\
4 & 5.25 & $* *$ & $*$ & $*$ & NS & - \\
\hline
\end{tabular}

${ }^{* * *} P \leq 0.001 ;{ }^{* *} P \leq 0.01 ;{ }^{*} P \leq 0.05 ; \mathrm{NS}=$ Not significant.

some previous works (Heikkila et al., 1982; Gedamu et al., 1983; Lindquist, 1986; Pascoe, 1990) suggest the transiency of heat shock response under mildly stressful conditions, it seems more logical, based on the already known functions of the SPs, to expect that they keep increasing in concentration, within certain limits, as has been demonstrated in Mytilus under temperature stress by Sanders et al. (1992). This approach has much support, while the intensity of the stress is not lethal and it is possible for the animal to adapt. In this case, the persistence of the stress response may correlate with the intensity of the stressor. However, continuous exposure to severe environmental conditions may lead to a state in which the animal can no longer maintain the stress protein response. In this case, the damages would already be noticed at the organismal level but the stress response would have disappeared. Nascimento et al. (1994) showed that the clam Corbicula fluminea, when subjected to extreme temperature shock $\left(38^{\circ} \mathrm{C}\right)$, suffers a depression in SP60 synthesis after $8 \mathrm{~h}$ of exposure and ultimately dies, while at $35^{\circ} \mathrm{C}$ the stress protein response persists over time. The higher toxicities of aquatic substrates at Stations 1 and 4 (Nascimento, 1996) are evidence of chronic stress, but the high values of stress response at Station 4 are probably evidence of a perturbed physio- 
Table 4

Dendogram, using average linkage (UPGMA) between groups and Gower's general similarity coefficient, of the similarities among the six sampling stations based on the relative concentrations of stress proteins in juvenile mangrove oysters (Crassostrea rhizophorae)

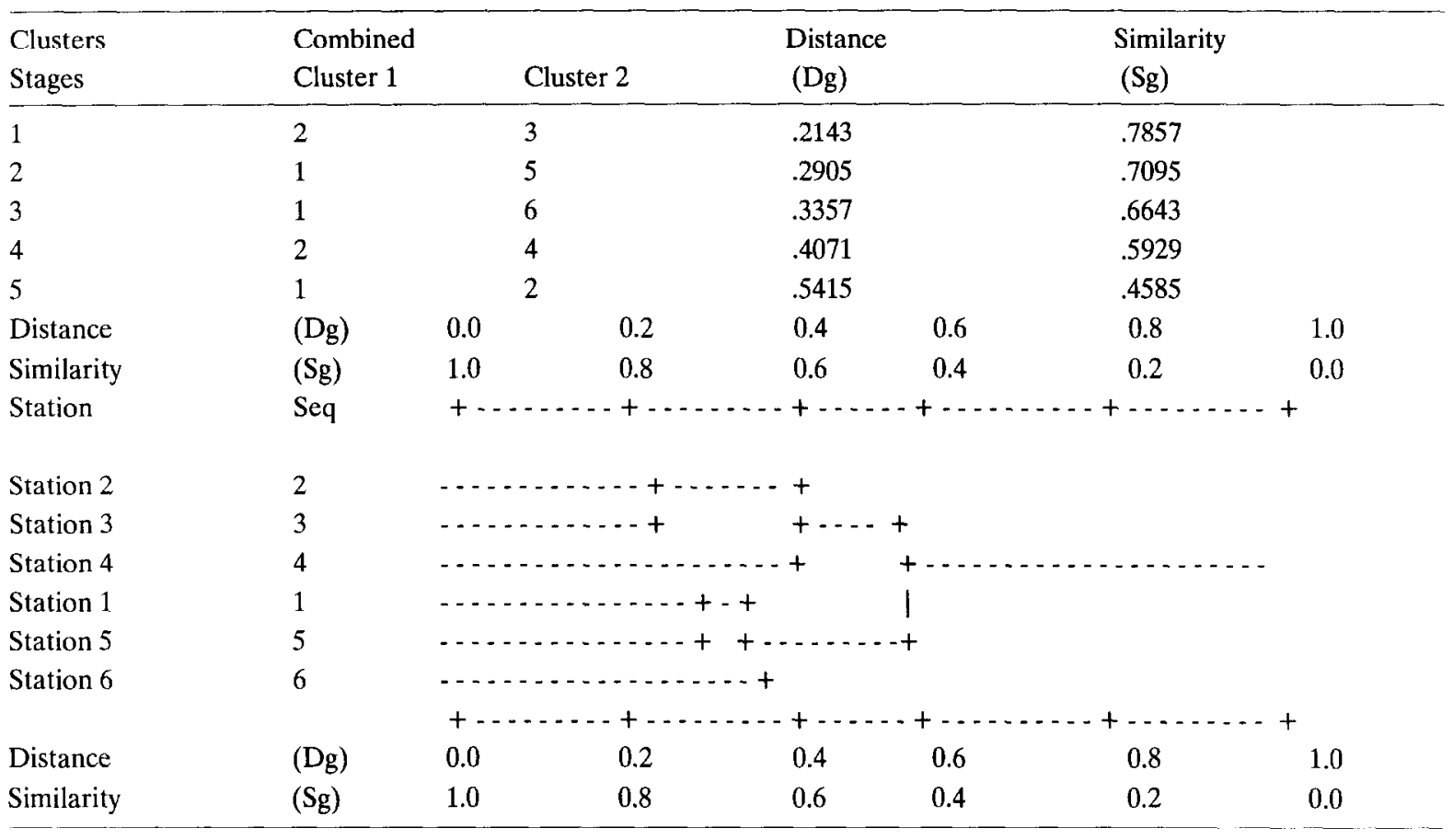

logical state from which the animal can still recover. The same conclusions can be drawn in relation to Stations 2 and 3 , where the concentrations of SP60 were also elevated.

Other cellular parameters, such as changes in the frequency of micronuclei in response to pollution, have been reported as being limited to situations in which sample stations lie within a range of environmental conditions which do not induce mortality (Brunetti et al., 1988). When the animals are subjected to extremely disturbed conditions, these genetic damages cannot be manifested since the polluting agents are probably causing premitotic cell death.

\section{Conclusions}

The results of this research suggest that the use of stress proteins may not serve as an indicator of environmental perturbation in situations where the response to stress, at or near the lethal tolerance limit, is evident at the organismal level (as in Station 1). The stress protein response may serve as a valid biomonitoring tool under chronic, sublethal exposures (as observed at Stations 4, 3 and 2 ), when it is still possible to prevent the biological consequences of exposures which affect organismal or higher organizational levels.

\section{Acknowledgements}

The authors wish to thank Petróleo Brasileiro S/A - Petrobrás, the Brazilian national petroleum company, for the financial and logistical support of this study, via Contracts 220.2.045.93-5 and 220.2.051.94-8 with the Federal University of Bahia, and to Cristiano Fernandes Santana, Adriana Caribé Marques and Cristiane Costa for their help in running the protein analysis. 


\section{References}

Ashburner, M., Bonner, J., 1979. The indicator of gene activity in Drosophila by heat shock. Cell 7, 241-254.

Blattler, D.P., Garner, F., Van Slyke, K., Bradley, A., 1972. Quantitative electrophoresis in polyacrylamide gels of 2\%-40\%. J. Chromatogr. 64, 147-155.

Bradford, M.M., 1976. A rapid and sensitive method for the quantities of protein utilizing the principle of proteindye binding. Anal. Biochem. 72, 248-254.

Brunetti, R., Majone, F., Gola, I., Beltrame, C., 1988. The micronucleans test: examples of application to marine ecology. Mar. Ecol. Prog. Ser. 44, 65-68.

Conover, W.J., 1971. Practical Nonparametric Statistics. Wiley, New York.

Convington, S.M., 1992. The stress protein response of Pimephales promelas to copper. MS thesis. University of North Texas.

Deshaies, R.J., Koch, B.D., Weiner-Washiburne, M., Craig, E., Schekman, R., 1988. A subfamily of stress proteins facilitates translocation of secretory and mitochondrial precursor polypeptides. Nature $332,800-805$.

Dyer, S.D., 1991. Evaluation of the efficacy of the stress protein response as a biochemical water quality biomonitoring method. PhD thesis. University of North Texas, Denton.

Gedamu, L., Culham, B., Heikkila, J.J., 1983. Analysis of the temperature-dependent temporal pattern of heatshock-protein synthesis in fish cells. Biosci. Rep. 3, 647-658.

Heikkila, J.J., Shultz, G.A., Iatrou, K., Gedamu, L., 1982. Expression of a set of fish genes following heat or metal ion expression. J. Biol. Chem. 257, 12000-12005.

Laemmli, U.K., 1970. Cleavage of structural proteins during assembly of the head of bactriophage T4. Nature 227, 680-685.

Lindquist, S., 1986. The heat shock response. Annu. Rev. Biochem. 55, 1151-1191.

Nascimento, I.A., Dickson, K.L., Zimmerman, E.G., 1994. Heat shock protein response to thermal stress in the Asiatic clam Corbicula fluminea I Simpósio Latino- americano de Saúde de Ecossistemas Aquáticos e Significado Ecológico de Bioensaios. São Carlos/SP. 17-20 de Outubro.
Nascimento, I.A., 1996. Relatorio setorial final do sub-projeto 'Testes ecotoxico-lógicos' do Programa de Monitoramento da Baía de Todos os Santos, 1994-1996. Convênio PETROBRAS/UFBA. Março.

Neff, J.M., 1984. Use of biochemical measurements to detect pollutant mediated damage to fish. In: Cordwell, R.D., Purdy, R., Bahner, R.C. (Eds.), Aquatic Toxicology and Hazard Assessment. Seventh Symposium, ASTM STP 854. American Society for Testing and Materials Philadelphia, pp. 155-183.

Pascoe, V.M., 1990. Synthesis and accumulation of stress proteins in Mytillus edulis during a two-week heat exposure treatment. Ms. thesis. California State University at Long Beach.

Peso de Aguiar, M.C., Almeida, V.G., 1996. Programa de Monitoramento dos Ecossistemas ao Norte da Baía de Todos os Santos, Relatório Gerencial final. Convênio UFBA/PETROBRAS nos. 220.2.045.93-5 e 220.2.051. 94-8, Salvador, Bahia, Brasil.

Rosen, E., Sivertsen, A., Firstel, R.A., Wheeler, S., Loomis, W.F., 1986. Heat shock genes of Dictyostelium. In: Atkinson, B.G., Woldeneds, D.B. (Eds.), Changes in Eukaryotic Gene Expression in Response to Environmental Stress. Academic Press, Florida, pp. 257-278.

Rothman, J.R., 1989. Polypeptide chain binding proteins: catalysts of protein folding and related processes in cells. Cell 59, 591-601.

Sanders, B.M., 1990. Stress proteins, potential as multitiered biomarkers. In: McCarthy, J., Shugart (Eds), Biomarkers of Environmental Contamination. Lewis, Chelsea, MI, USA.

Sanders, B.M., Hope, C., Pascoe, V.M., Martin, L.S., 1991. Characterizations of stress proteins response in two species of Colisella limpets with different tempcraturc tolerances. Physiol. Zool. 64, 1471-1489.

Sanders, B.M., Pascoe, V.M. Nakagawa, P.A., Martin, L.S., 1992. Persistence of the heat-shock response over time in common Mytillus mussel. Mol. Mar. Biol. Biotechnol. $1,147-154$.

Schlesinger, M.J., 1986. Heat shock proteins: the search for functions. J. Cell. Biology. 1093, 321-325.

Sneath, P.H.A., Soka, R.R., 1973. Numeric Taxonomy. W.H. Freemand and Company, San Francisco, CA. 